Atmos. Chem. Phys., 13, 10339-10352, 2013

www.atmos-chem-phys.net/13/10339/2013/

doi:10.5194/acp-13-10339-2013

(c) Author(s) 2013. CC Attribution 3.0 License.

\title{
Examination of the atmospheric conditions associated with high and low summer ozone levels in the lower troposphere over the eastern Mediterranean
}

\author{
P. D. Kalabokas ${ }^{1}$, J.-P. Cammas ${ }^{2}$, V. Thouret ${ }^{2}$, A. Volz-Thomas ${ }^{3}$, D. Boulanger ${ }^{2}$, and C. C. Repapis ${ }^{1,4}$ \\ ${ }^{1}$ Academy of Athens, Research Center for Atmospheric Physics and Climatology, Athens, Greece \\ ${ }^{2}$ Laboratoire d'Aerologie, UMR5560, Universite Paul Sabatier, Toulouse, France \\ ${ }^{3}$ Institut fuer Chemie and Dynamik der Geosphaere, Forschungszentrum Juelich, Germany \\ ${ }^{4}$ Mariolopoulos-Kanaginis Foundation for the Environmental Sciences, Athens, Greece \\ Correspondence to: P. D. Kalabokas (pkalabokas@academyofathens.gr)
}

Received: 30 October 2012 - Published in Atmos. Chem. Phys. Discuss.: 23 January 2013

Revised: 7 June 2013 - Accepted: 19 September 2013 - Published: 23 October 2013

\begin{abstract}
In order to evaluate the observed high rural ozone levels in the eastern Mediterranean area during summertime, vertical profiles of ozone measured in the period 1994-2008 in the framework of the MOZAIC project (Measurement of Ozone and Water Vapor by Airbus in Service Aircraft) over the eastern Mediterranean basin (Cairo, Tel Aviv, Heraklion, Rhodes, Antalya) were analyzed, focusing in the lower troposphere $(1.5-5 \mathrm{~km})$. At first, vertical profiles collected during extreme days with very high or very low tropospheric ozone mixing ratios have been examined together with the corresponding back-trajectories. Also, the average profiles of ozone, relative humidity, carbon monoxide, temperature gradient and wind speed corresponding to the $7 \%$ highest and the $7 \%$ lowest ozone mixing ratios for the $1500-5000 \mathrm{~m}$ height layer for Cairo and Tel Aviv have been examined and the corresponding composite maps of geopotential heights at $850 \mathrm{hPa}$ have been plotted. Based on the above analysis, it turns out that the lower-tropospheric ozone variability over the eastern Mediterranean area is controlled mainly by the synoptic meteorological conditions, combined with local topographical and meteorological features. In particular, the highest ozone concentrations in the lower troposphere and subsequently in the boundary layer are associated with largescale subsidence of ozone-rich air masses from the upper troposphere under anticyclonic conditions while the lowest ozone concentrations are associated with low pressure conditions inducing uplifting of boundary-layer air, poor in ozone and rich in relative humidity, to the lower troposphere.
\end{abstract}

\section{Introduction}

Tropospheric ozone plays an important role in atmospheric climate, being an important greenhouse gas, and also in the physico-chemical processes of the troposphere, as it is a major source of tropospheric free radicals responsible for the oxidation of many atmospheric substances (Finlayson-Pitts and Pitts, 1997). The presence of ozone near the ground surface is also important because of its strong oxidant properties, which may cause damage to humans, animals, vegetation and materials at certain concentration levels (Bates, 1994).

The high summer ozone levels in the Mediterranean basin and especially in its eastern part have attracted the attention of research scientists and have been the subject of many field studies on air pollution in the area during recent years (e.g. Varotsos et al., 1993; Kalabokas et al., 2000; Kourtidis et al., 2002; Kouvarakis et al., 2002; Zerefos et al., 2002; Lelieveld et al., 2002; Roelofs et al., 2003; Kalabokas and Repapis, 2004). Such high summer levels are a general characteristic of the ozone vertical profiles in the region. Among all the recorded profiles in mid-latitudes, the MOZAIC (Marenco et al., 1998) database has revealed that this region is noteworthy by presenting such differences (i.e. up to $20 \mathrm{ppb}$ ) between spring and summer seasonal profiles throughout the free troposphere (Zbinden et al., 2013).

The weather conditions over the eastern Mediterranean during summer are influenced by eastward extensions of the Azores anticyclone and the low pressure branch of the large 
South Asian thermal low. Modelling studies of the largescale dynamics (Rodwell and Hoskins, 1996, 2001) also suggest a strong influence of the Indian Monsoon on the dry Mediterranean climate in summer, i.e. by Rossby wave interaction with the southern flank of the mid-latitude westerlies producing adiabatic descent and hence anticyclonic conditions at the surface over the western Mediterranean. The resulting monsoon circulation over the Aegean Sea, together with the strong pressure gradient due to the surrounding mountains of the Greek peninsula in the west and the Anatolian plateau in the east, produces persistent northerly winds, the so-called "Etesian winds" (annual winds). This flow of the low troposphere is most pronounced at the $850 \mathrm{hPa}$ level (Repapis et al., 1977). As a result, the eastern Mediterranean is influenced by advection from Europe in the lower troposphere, associated with the Etesian winds and subsidence in the middle and upper troposphere associated with the westerly flow in the descending branches of the Asian thermal low and, to a lesser extent, of the East African monsoon. It was also shown that the day-to-day variations in these two main factors are linked to the Asian monsoon (Rodwell and Hoskins, 2001; Lelieveld et al., 2002; Ziv et al., 2004; Tyrlis et al., 2012).

In addition, the possibility for an influence of long-range transport from the European continent, North America and Southeast Asia on ozone and its precursors over the eastern Mediterranean troposphere has been discussed (Van Aalst, 1996; Volz-Thomas et al., 2003) and has been studied in more detail during two intensive measuring campaigns (MINOS and PAUR) over the Aegean (e.g. Lelieveld et al., 2002; Zerefos et al., 2002; Kourtidis et al., 2002; Kouvarakis et al., 2002; Gros et al., 2003; Roelofs et al., 2003; Scheeren et al., 2003; Traub et al., 2003).

In order to address the above issues and as the first phase of the present study, vertical ozone profiles measured in the period 1996-2002 in the framework of the MOZAIC (Measurement of Ozone and Water Vapor by Airbus in Service Aircraft) project (Marenco et al., 1998) for flights connecting central Europe to the eastern Mediterranean basin (Heraklion, Rhodes, Antalya) have been analyzed (Kalabokas et al., 2007). The 77 flights during summer (JJA) showed over the eastern Mediterranean significantly (10-12 ppb, 20-40\%) enhanced ozone mixing ratios in the lower troposphere and especially at the 1000-700 hPa layer, where ozone frequently exceeds the $60 \mathrm{ppb}, 8 \mathrm{~h}$ EU air quality standard, whereas ozone between 700 and $400 \mathrm{hPa}$ was only slightly (3-5 ppb, $5-10 \%$ ) higher than over central Europe. Analysis of composite weather maps for the high and low ozone cases in the boundary layer, as well as back-trajectories and vertical profiles of carbon monoxide, suggest that the main factor leading to high tropospheric ozone values in the area is anticyclonic influence, in combination with a persistent northerly flow in the lower troposphere and the boundary layer during summertime over the Aegean Sea. On the other hand, the lowest ozone levels are associated with the passing of low-pressure systems, or the extension to the west of the Middle Eastern low associated with weak pressure gradients over the eastern Mediterranean and an upper air trough in northeastern Europe. The same pattern of summer ozone variability has been observed by analyzing the ozone measurements at several rural sites in the eastern and central Mediterranean (Kalabokas et al., 2008), showing that the highest and lowest summer afternoon ozone levels are strongly associated with characteristic synoptic meteorological conditions prevailing throughout the whole lower troposphere.

The aim of this work is to investigate the meteorological and/or chemical factors controlling the lower-troposphere ozone levels, above the boundary layer (1.5-5 km altitude) over the eastern Mediterranean, as a continuation of our previous study and with the scope to better understand the ozone variations observed inside the boundary layer and at the surface of the examined region. The area under study has been extended towards the Middle East region (Cairo, Tel Aviv), where a significant number of MOZAIC vertical profiles has been recorded over the respective airports, during the period 1994-2008. Thus, vertical MOZAIC summer ozone profiles obtained during approach and departure (horizontal distance covered is probably $100-200 \mathrm{~km}$ ), in the period 1994-2008 over the eastern Mediterranean airports of Cairo, Tel Aviv, Heraklion, Rhodes and Antalya were analyzed in order to improve our knowledge of the atmospheric conditions associated with high and low ozone levels in the lower troposphere. In addition, in this study the measurements of relative humidity, temperature, wind speed and carbon monoxide have been examined in parallel with the ozone measurements. In this respect, vertical profiles of the above-mentioned parameters collected during days with very high or very low ozone mixing ratios in the lower troposphere have been examined together with the corresponding back trajectories and the composite weather maps.

\section{Data}

Since 1994, within the framework of the MOZAIC program (Marenco et al., 1998) five commercial airliners have been equipped with instruments to measure ozone, water vapor, and (since 2002) carbon monoxide. Measurements are taken from take-off to landing so that vertical profiles can be obtained near airports, in addition to the measurements at cruising altitude. Based on the dual-beam UV absorption principle (Thermo-Electron, Model 49-103), the ozone measurement accuracy is estimated at $\pm[2 \mathrm{ppbv}+2 \%]$ for a $4 \mathrm{~s}$ response time (Thouret et al., 1998). Based on an infrared analyzer, the carbon monoxide measurement accuracy is estimated at $\pm 5 \mathrm{ppbv} \pm 5 \%$ (Nédélec et al., 2003) for a $30 \mathrm{~s}$ response time. The MOZAIC data base (http://www.iagos. $\mathrm{fr} / \mathrm{web} /$ ) was screened for summer (JJA) flights at the airports of the eastern Mediterranean basin. In total, 237 summer profiles were analyzed with the following distribution: 


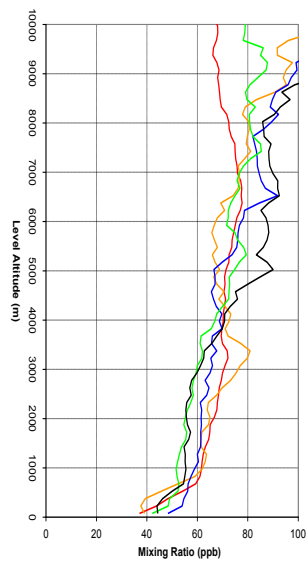

OZONE

(a)

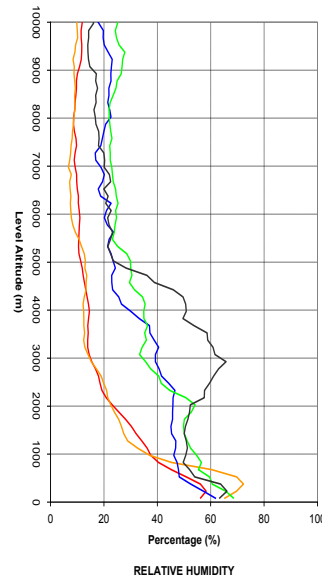

(b)

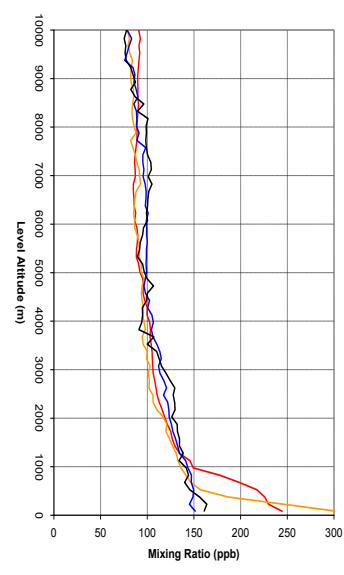

co

(c)

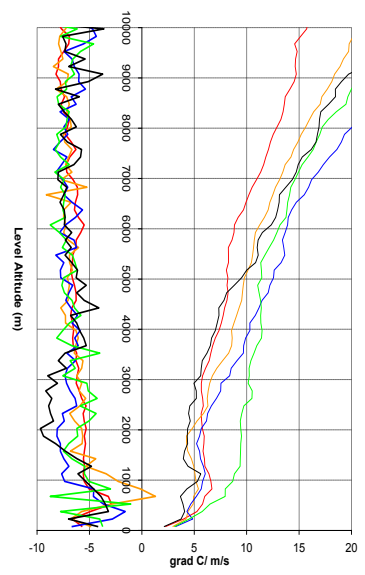

TEMPERATURE GRADIENT Per KM / WIND SPEED

(d)

Fig. 1. (a) Vertical profiles of summer (JJA) ozone over the eastern Mediterranean airports of Cairo (red), Tel Aviv (orange), Antalya (black), Heraklion (green) and Rhodes (blue), for 1994-2008; (b) same as (a) but for relative humidity; (c) same as (a) but for carbon monoxide (CO); (d) (left), same as (a) but for temperature gradient per km; (right), same as (a) but for wind speed.

94 profiles over Cairo $\left(30.1^{\circ} \mathrm{N}, 31.2^{\circ} \mathrm{E}\right)$, Egypt, 85 profiles over Tel Aviv ( $\left.32.1^{\circ} \mathrm{N}, 34.8^{\circ} \mathrm{E}\right)$, Israel, 36 profiles in total over Heraklion $\left(35.3^{\circ} \mathrm{N}, 25.2^{\circ} \mathrm{E}\right)$ and Rhodes $\left(36.4^{\circ} \mathrm{N}\right.$, $\left.28.1^{\circ} \mathrm{E}\right)$, Greece and 22 profiles over Antalya $\left(36.8^{\circ} \mathrm{N}\right.$, $30.8^{\circ} \mathrm{E}$ ), Turkey. The analyzed flights cover the period 1994 2008 between June and August. Both ascent and descent data have been used.

\section{Results and discussion}

\subsection{Average vertical profiles over the eastern Mediterranean airports}

In Fig. 1 the vertical average summer (JJA) profiles of ozone, relative humidity, carbon monoxide, vertical temperature gradient and wind speed over the eastern Mediterranean airports of Cairo, Tel Aviv, Antalya, Heraklion and Rhodes for 1994-2008 are presented. As displayed in Fig. 1a the boundary-layer $(0-1 \mathrm{~km}$ in general) ozone concentrations over all examined airports are lower than the freetroposphere ozone concentrations (by about 20-30\%) with minimum values observed at the ground surface. The lower troposphere ozone mixing ratios above the boundary layer, over Cairo and Tel Aviv are by 10-15\% higher than the corresponding values over Antalya and Heraklion and about 5$10 \%$ higher than the values over Rhodes (Fig. 1a).

Relative humidity (RH) levels (Fig. 1b) inside the boundary layer are higher than the corresponding lower troposphere levels over all airports. The lower troposphere relative humidity levels over Cairo and Tel Aviv are by about $50 \%$ lower than over Heraklion and Rhodes, and about $65 \%$ lower than over Antalya, at the 2-4 km layer (Fig. 1b).
Because of its low solubility and its photochemical lifetime of the order of weeks, carbon monoxide (CO) is a good tracer of anthropogenic pollution. CO profiles have been used for tracking pollution episodes in the boundary layer or even in the free troposphere (cf., Seiler and Fishman, 1981; Nédélec et al., 2003). The boundary-layer CO levels (Fig. 1c) in Cairo and Tel Aviv are by a factor of 2-3 higher than the lower troposphere levels, which are slightly lower than the corresponding levels over Antalya and Rhodes. The boundary-layer levels of $\mathrm{CO}$ over Rhodes and Antalya are about $20 \%$ higher than the corresponding levels of the lower troposphere. The temperature gradient (Fig. 1d) in the lower troposphere is between -5 and $-10^{\circ} \mathrm{C} \mathrm{km}^{-1}$, the steepest gradients being observed over Antalya and Rhodes. The wind speed in the lower troposphere is between 5 and $10 \mathrm{~m} \mathrm{~s}^{-1}$ and the highest values are recorded over Heraklion, being more exposed to the northerly air flow of the Etesian winds (Repapis et al., 1977).

\subsection{Case studies of very high and very low ozone profiles}

Five vertical profiles measured over Cairo during a 3-day period (30 July-1 August 2003) with very high ozone levels in the lower troposphere and the boundary layer are examined separately (Fig. 2). During this characteristic high ozone period, the vertical profiles of ozone over Cairo exhibit ozone values in the range of $70-100 \mathrm{ppb}$ above $1500 \mathrm{~m}$ (Fig. 2a). The corresponding vertical relative humidity profiles above $2 \mathrm{~km}$ show very low levels, $0-20 \%$, indicating origin of air masses from the upper troposphere-lower stratosphere (UTLS) region (Fig. 2b). The $\mathrm{CO}$ values in the boundary layer are about $200-350 \mathrm{ppb}$ and about $100 \mathrm{ppb}$ in the lower troposphere (Fig. 2c), which are typically upper troposphere 


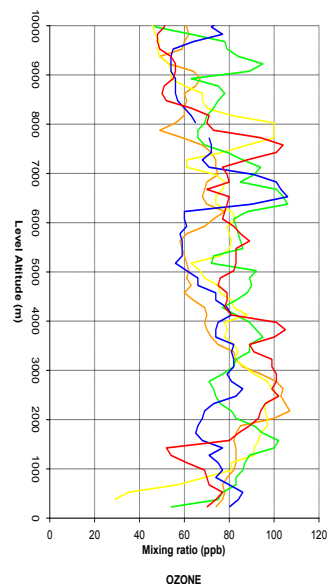

(a)

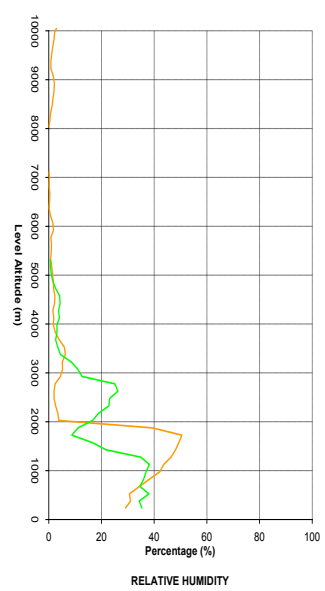

(b)

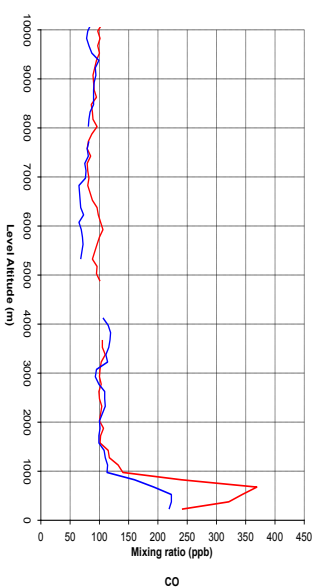

(c)

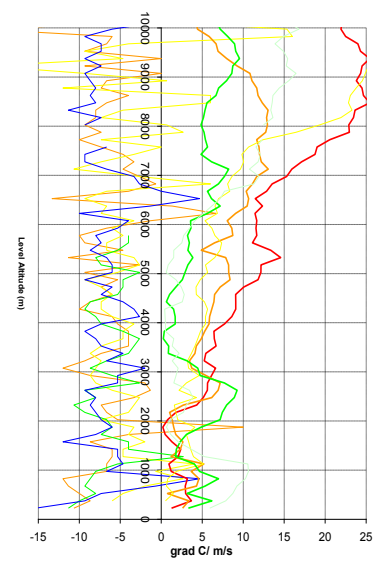

TEMPERATURE GRADIENT Per KM / WIND SPEED

(d)

Fig. 2. (a) Vertical profiles of summer (JJA) ozone over the eastern Mediterranean airport of Cairo during the 3-day high ozone period in the lower troposphere, 30 July-1 August 2003 (Profiles: MD20030730023 (red), MA20030730063 (orange), MA20030730103 (yellow), MA20030801063 (green), MD20030801054 (blue); (b) same as (a) but for relative humidity; (c) same as (a) but for carbon monoxide (CO); (d) (left), same as (a) but for temperature gradient per km; (right), same as (a) but for wind speed. There are missing profiles in (b) and (c).

background values (Nédélec et al., 2003, 2005). The vertical temperature gradient indicates strong inversions at the $1-2 \mathrm{~km}$ layer, while the wind speed shows stagnant meteorological conditions up to $2.5 \mathrm{~km}$, and low winds for the rest of the lower troposphere (Fig. 2d).

For the determination of the air-mass origin, the Lagrangian particle dispersion model FLEXPART (version 6.2; Stohl et al., 1998, 2005) was used. FLEXPART was driven by model-level data from the European Center for MediumRange Weather Forecasts (ECMWF), with a temporal resolution of $3 \mathrm{~h}$ (analysis at 00:00, 06:00, 12:00, 18:00 UTC; $3 \mathrm{~h}$ forecasts at 03:00, 09:00, 15:00, 21:00 UTC), and 60 vertical levels. Horizontal resolution was globally $1 \times 1^{\circ} .20000$ particles were released from grid boxes $\left(0.5 \times 0.5^{\circ}, 100 \mathrm{~m}\right.$ in height) centered on the MOZAIC profiles.

Shown in Fig. 3 is the backward integration in time, for 3 days and for the $1.5-5 \mathrm{~km}$ layer, for a MOZAIC vertical profile over Cairo (among the five cited above) during a day with high ozone levels in the lower troposphere (30 July 2003, Flight: MA20030730103). The results are summarized on centroids of 5 clusters (the method to condense the large and complex FLEXPART output using a cluster analysis as further described in Stohl et al., 2005), and include every $12 \mathrm{~h}$ latitude, longitude, pressure and percentage of representation (the fraction of particles belonging to the cluster). The back-trajectories corresponding to this profile show mostly descending upper troposphere air masses from over the Aegean, the central Mediterranean and western Europe, which is a typical picture describing the atmospheric circulation on the fringe of anticyclonic conditions.

On the other hand, during a characteristic 2-day low ozone period (26-27 July 2002) in the lower troposphere (Fig. 4) the summer vertical profiles of ozone over Cairo show significantly low ozone values at $25-45 \mathrm{ppb}$, with a minimum in the $1.5-3.5 \mathrm{~km}$ layer (Fig. 4a). On the contrary, compared to the high ozone period, the corresponding vertical profiles of humidity show considerably higher values in the range of $25-60 \%$ in the $1-4.5 \mathrm{~km}$ layer. These relatively high humidity levels indicate the presence of air masses originating from the boundary layer. A gradual increase of humidity is observed with increasing altitude with a maximum at $4-5 \mathrm{~km}$ (Fig. 4b). The $\mathrm{CO}$ values in the boundary layer and the lower troposphere (Fig. 4c) are quite comparable to the corresponding levels of the high ozone profile. The sharp decrease of air temperature with increasing altitude approaching dry adiabatic lapse rate at $3-4 \mathrm{~km}$ indicating weaker static stability where the wind speed shows relatively high values (Fig. 4d).

In Fig. 5 the backward integration in time, for 3 days and for the $1.5-5 \mathrm{~km}$ layer, for a MOZAIC vertical profile over Cairo during a day with low ozone levels in the lower troposphere (26 July 2002, Flight: MD20020726023) is presented. The back-trajectories corresponding to this low-ozone profile show more rapidly moving western air masses originating from the lower troposphere and the boundary layer from over the central and western Mediterranean and subsequently from over the Atlantic (for a period longer than 3 days before the measurement).

For a more accurate assessment of the origin of air masses and their vertical transport, in Table 1, the calculations of the contribution of different tropospheric layers to the air masses arriving over Cairo (at $1.5-5 \mathrm{~km}$ ) for the highest ozone case over Cairo on 30 July 2003 are presented, based on the FLEXPART back-trajectories (shown also in Fig. 3). As observed in Table 1, the contribution of the upper troposphere 


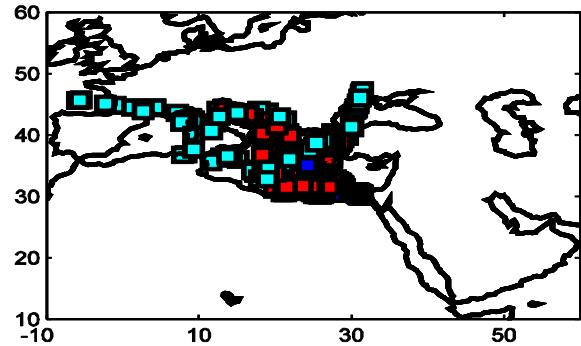

Clusters In backward trajectorles at Do (black), D-1 (blue), D-2 (red), D-3 (cyan)
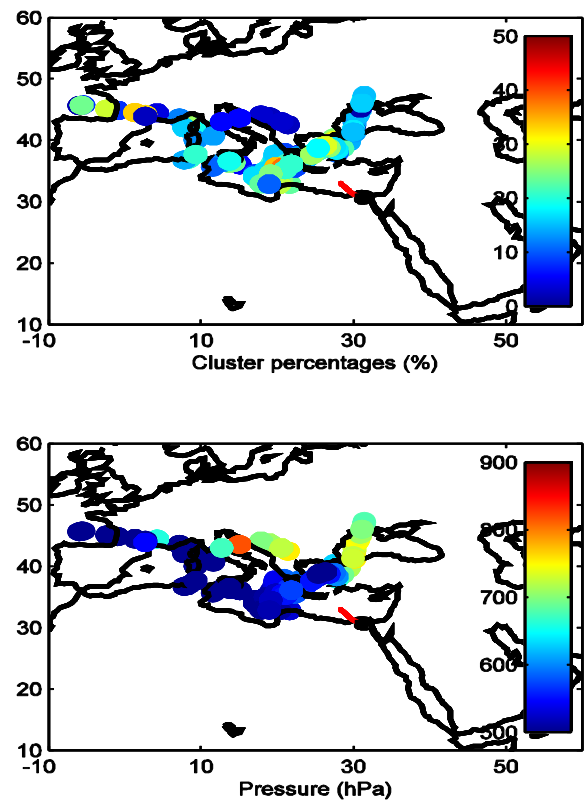

Fig. 3. Backward integration in time for 3 days for the MOZAIC vertical profile measurements and for air masses arriving at 1500 $5000 \mathrm{~m}$ over Cairo during a period with high ozone levels in the lower troposphere (30 July 2003, Flight: MA20030730103). The results are summarized on centroids of 5 clusters, and include every $12 \mathrm{~h}$ latitude, longitude, pressure and percentage of representation. The results shown above are for the $1.5-5 \mathrm{~km}$ layer. Top plot shows the clusters positions at day 0 (black), day-1 (blue), day-2 (red), and day-3 (cyan). Middle plot shows the percentages of clusters at day3. Finally, bottom plot shows the pressure of the clusters at day-3. The red line is the aircraft trajectory during ascent/descent.

air masses $(>500 \mathrm{hPa})$ to the air arriving to the $1.5-5 \mathrm{~km}$ layer is very significant (about $53 \%$ of the air parcels, 3 days before the measurement). On the contrary, there is no measurable contribution of the boundary-layer air $(>850 \mathrm{hPa})$ and only about $4 \%$ contribution from air masses below $700 \mathrm{hPa}$ to the $1.5-5 \mathrm{~km}$ layer for 3 days before the measurement.

In Table 2, the corresponding calculation of the contribution of different tropospheric layers to the air masses arriving over Cairo (at $1.5-5 \mathrm{~km}$ ) for the lowest ozone case over Cairo on 26 July 2002 are presented (FLEXPART backtrajectories shown also in Fig. 5). In this case the picture is
Table 1. Percentage contribution of each atmospheric layer to the air arriving on a high ozone day in Cairo at $1.5-5 \mathrm{~km}$ on 30 July 2003 (Flight: MA20030730103), for 1-day, 2-day and 3-day FLEXPART backward simulations.

\begin{tabular}{lccc}
\hline & 1 day & 2 days & 3 days \\
\hline $0-850 \mathrm{hPa}$ & 4.4 & 0.2 & \\
$850-700 \mathrm{hPa}$ & 19.4 & 18.1 & 3.5 \\
$700-500 \mathrm{hPa}$ & 39.2 & 36.3 & 43.3 \\
$>500 \mathrm{hPa}$ & 37.1 & 45.4 & 53.2 \\
\hline Total & 100 & 100 & 100 \\
\hline
\end{tabular}

Table 2. Percentage contribution of each atmospheric layer to the air arriving on a low ozone day in Cairo at $1.5-5 \mathrm{~km}$ on 26 July 2002 (Flight: MD20020726023), for 1-day, 2-day and 3-day FLEXPART backward simulations.

\begin{tabular}{lccc}
\hline & 1 day & 2 days & 3 days \\
\hline $0-850 \mathrm{hPa}$ & 15.7 & & 0.5 \\
$850-700 \mathrm{hPa}$ & 23.0 & 83.8 & 40.3 \\
$700-500 \mathrm{hPa}$ & 47.2 & 11.1 & 55.5 \\
$>500 \mathrm{hPa}$ & 14.2 & 5.2 & 3.7 \\
\hline Total & 100 & 100 & 100 \\
\hline
\end{tabular}

substantially different if compared to Table 1 . The upper troposphere contribution $(>500 \mathrm{hPa}$ ) is only about $4 \%$ while contribution from air masses below $700 \mathrm{hPa}$ to the $1.5-5 \mathrm{~km}$ layer for 3 days before the measurement is about $41 \%$.

During the same 3-day high ozone period over Cairo presented in Fig. 2 (30 July-1 August 2003), four vertical profiles have been also recorded over Tel Aviv, (Fig. 6). The comparison between Figs. 6 and 2 shows that almost the same characteristics in the profiles of ozone (high ozone values in the range of $80-100 \mathrm{ppb}$ in the $2-4 \mathrm{~km}$ layer), relative humidity, $\mathrm{CO}$, wind speed and vertical temperature gradient are observed during the same period over Tel Aviv and Cairo, indicating comparable ozone vertical distribution patterns in the lower troposphere over the entire southeastern Mediterranean area during high ozone situations. The corresponding back-trajectories of Fig. 7 in combination with Fig. 3 confirm the described anticyclonic conditions which affect the lower troposphere ozone over the area (descending upper troposphere air masses over the eastern Mediterranean). It has to be added that in this case the calculated contribution to the $1.5-5 \mathrm{~km}$ layer from the upper troposphere $(>500 \mathrm{hPa})$ is about $30 \%$ while the contribution from air masses below $700 \mathrm{hPa}$ to the $1.5-5 \mathrm{~km}$ layer for 3 days before the measurement is about $21 \%$. 


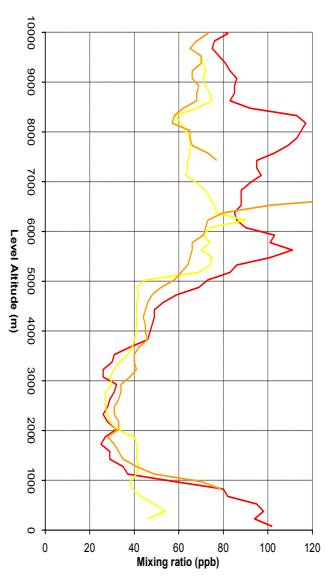

OZONE

(a)

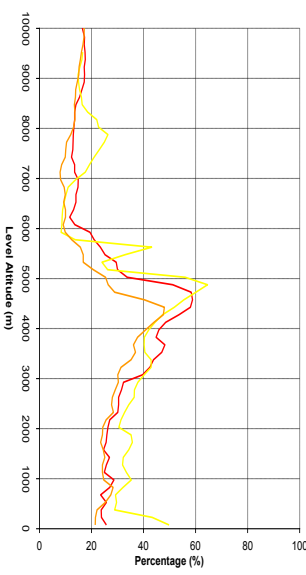

RELATIVE HUMDITY

(b)

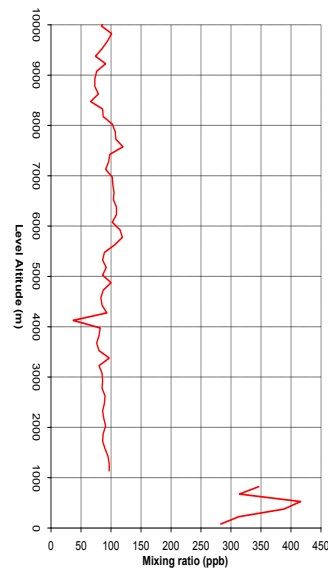

(c)

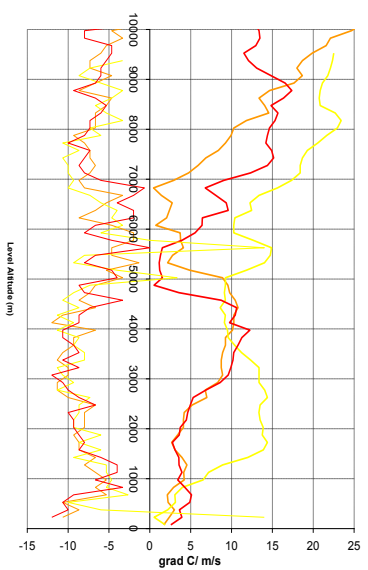

TEMPERATURE GRADIENT per KM / WIND SPEED

(d)

Fig. 4. (a) Vertical profiles of summer (JJA) ozone over the eastern Mediterranean airport of Cairo during the 2-day low ozone period in the lower troposphere, 26-27 July 2002 (Profiles: MA20020726043 (red), MD20020726023 (orange), MA20020727013 (yellow)); (b) same as (a) but for relative humidity; (c) same as (a) but for carbon monoxide (CO); (d) (left), same as (a) but for temperature gradient per km; (right), same as (a) but for wind speed. There are missing profiles in (c).

\subsection{Mean vertical profiles for highest and lowest ozone in the lower troposphere}

In the following figures the differences between highest and lowest ozone profiles are analyzed more systematically by taking into account more days with very high and very low ozone profiles. In Figs. 8 and 10 the summer vertical profiles of ozone over Cairo and Tel Aviv respectively for the $7 \%$ highest and the $7 \%$ lowest ozone mixing ratios at 1500 $5000 \mathrm{~m}$ are shown together with the corresponding curves of relative humidity, carbon monoxide, temperature gradient and wind speed. It is clearly observed that the $7 \%$ highest ozone concentrations in the lower troposphere over Cairo and Tel Aviv are associated with low relative humidity, low wind speed and low vertical temperature gradient values. On the other hand, the $7 \%$ lowest ozone concentrations at 1500$5000 \mathrm{~m}$ over Cairo and Tel Aviv are associated with higher relative humidity, high wind speed and high vertical temperature gradient values indicating vertical instability and ascending air movements. It is remarkable that, contrary to the large ozone and RH differences, the average CO levels are comparable between the highest and lowest ozone days over both airports, indicating comparable levels of primary pollution in the air masses under both examined conditions (highestlowest ozone).

Figures 9 and 11 display the composite weather maps of geopotential heights at $850 \mathrm{hPa}$ of the $7 \%$ of the days with the highest and the lowest ozone concentrations, at the 1500$5000 \mathrm{~m}$ layer, in Cairo and Tel Aviv, during the day of the measurement and 2 days ago. The composite weather maps were constructed from the NCEP/NCAR reanalysis, based on grids of $2.5 \times 2.5^{\circ}$, for the days of the flights in each group following the procedure of Kalnay et al. (1996). As observed in the $850 \mathrm{hPa}$ charts the highest ozone values at 1500 $5000 \mathrm{~m}$ over Cairo and Tel Aviv are associated with anticyclonic conditions prevailing over Europe and North Africa, the eastern Mediterranean being on the fringe of the anticyclonic circulation. On the contrary, the lowest ozone values are associated with the weakening of the North-African anticyclone, if compared to the highest ozone days, and low pressure conditions prevailing over eastern and northern Europe as well as over the Middle East. Comparable results were obtained during the first phase of the study by analyzing MOZAIC profiles over the Aegean airports (Kalabokas et al., 2007), indicating that over most of the eastern Mediterranean area the same processes are responsible for highest and accordingly lowest ozone. It is interesting to observe that in Cairo, both the anticyclonic and low pressure conditions at $850 \mathrm{hPa}$ corresponding to highest and lowest ozone respectively are more intense than those of Tel Aviv and at the same time the differences highest-lowest ozone are higher over Cairo at the corresponding to the $850 \mathrm{hPa}$ layer height $(1500-2000 \mathrm{~m})$. It has also to be mentioned that the corresponding composite weather maps of the higher levels at 700 and $500 \mathrm{hPa}$ (not shown) exhibit quite comparable patterns with the presented maps for the $850 \mathrm{hPa}$ layer.

In the Cairo profiles large differences between the lowest (35-40 ppb) and the highest (90-95 ppb) ozone levels are observed throughout the lower troposphere, up to $5 \mathrm{~km}$ (Fig. 8a). Over both airports of Cairo and Tel Aviv during the highest ozone days at all examined layers, very dry (5-20\% relative humidity) air masses are observed from the top of the boundary layer up to $5 \mathrm{~km}$ indicating upper troposphere (or stratospheric) origin, while for the $7 \%$ lowest ozone, the 

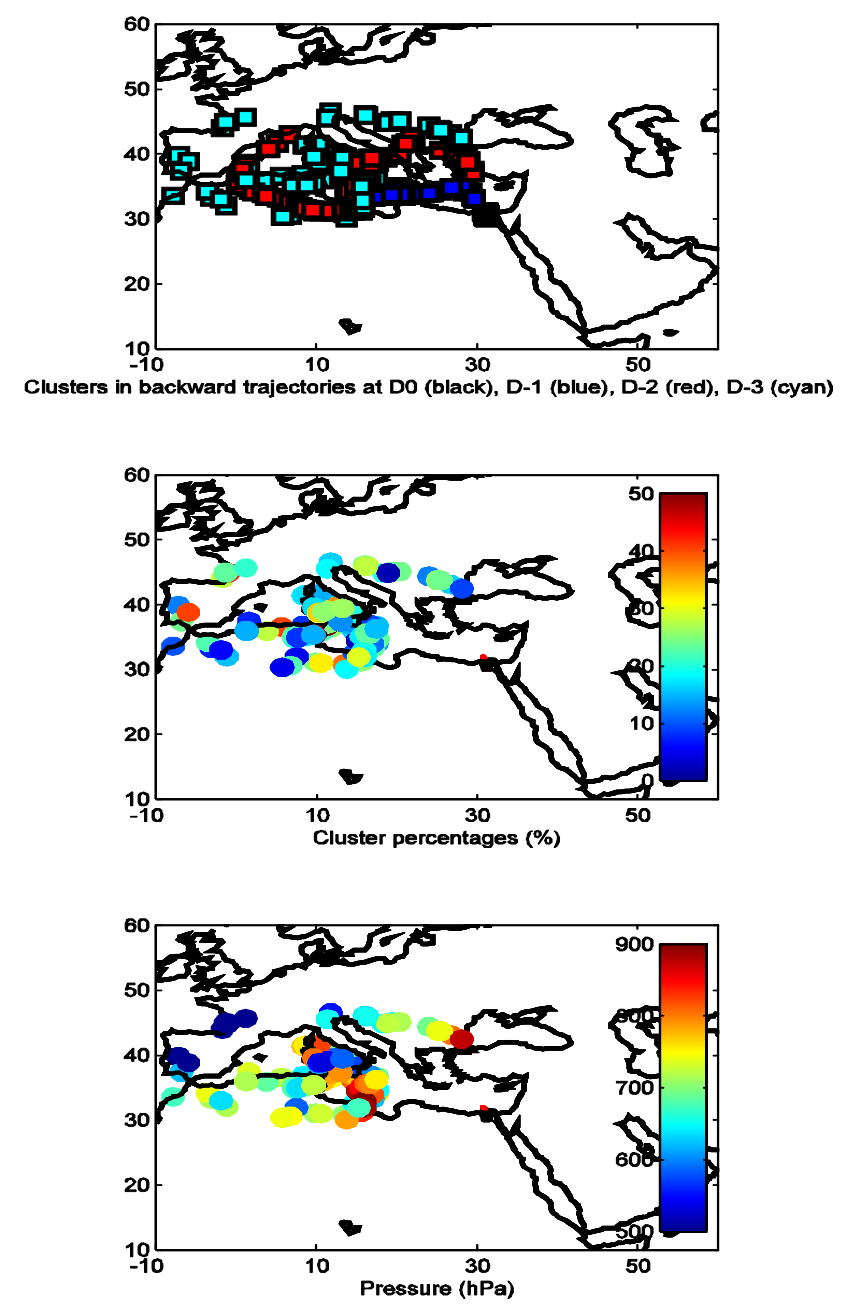

Fig. 5. Backward integration in time for 3 days for the MOZAIC vertical profile measurements and for air masses arriving at 1500$5000 \mathrm{~m}$ over Cairo during a period with low ozone levels in the lower troposphere (26 July 2002, Flight: MD20020726023). The results are summarized on centroids of 5 clusters, and include every $12 \mathrm{~h}$ latitude, longitude, pressure and percentage of representation. The results shown above are for the $1.5-5 \mathrm{~km}$ layer. Top plot shows the clusters positions at day 0 (black), day-1 (blue), day-2 (red), and day-3 (cyan). The middle plot shows the percentages of clusters at day-3. Finally, the bottom plot shows the pressure of the clusters at day-3. The red line is the aircraft trajectory during ascent/descent.

relative humidity is substantially higher in the same atmospheric region (up to $60 \%$ ), indicating uplifting of boundarylayer air masses (with low ozone and high relative humidity) towards the lower troposphere (Figs. 8, 10). An interesting observation is that the smaller differences between highest and lowest ozone at $1500-3000 \mathrm{~m}$ in Tel Aviv compared to Cairo are also associated with smaller (almost negligible) corresponding differences in relative humidity, wind speed and vertical temperature gradient values. This is an indication that local meteorological factors in Tel Aviv, such as the creation of local sea-breeze cells across the shoreline, do not allow the creation of atmospheric instability conditions below $3 \mathrm{~km}$ as observed in Cairo, which is located further inland and influenced by the Saharan dessert.

As previously noticed, in contrast to the relative humidity, the CO (Figs. 8c, 10c) levels are in general comparable between the highest and lowest ozone days with only slightly higher values below $2 \mathrm{~km}$ height during the highest ozone days, indicating increased influence of air pollution. The comparable $\mathrm{CO}$ average levels in comparison to the large difference in ozone concentrations between the highest and the lowest ozone days is a strong indication that the meteorological conditions are mainly the regulating factor of the lower tropospheric ozone levels, concerning the short-term variability (several days). Photochemical ozone production might play an important role over longer timescales (weeks) and larger geographical scales (hemispheric or global) but not in the short-term local tropospheric variability over the examined region.

The wind speed at all examined layers (Figs. 8d, 10d) is higher for the lower ozone cases, which is to be expected during low-pressure weather conditions. Also the temperature gradient in the lower troposphere is steeper for the lowest ozone days indicating vertical instability favoring the uplifting of boundary-layer air masses to higher levels.

As observed on the composite weather maps (Figs. 9, 11) the highest ozone concentrations in the lower troposphere and the boundary layer occur during high pressure (anticyclonic) conditions, extended over large areas in western and central Europe as well as over the Mediterranean and North Africa. These atmospheric conditions are generally associated with the transport and subsidence of air masses from the higher tropospheric layers, which might lead to increase in ozone and decrease in relative humidity. Under such conditions, the boundary-layer ozone is expected to increase due to the influence of the high ozone values in the lower troposphere, maximized in the afternoon hours when the daily maximum of the boundary-layer mixing height, caused by the thermal instability, occurs, transporting down to the surface ozone-rich air masses located above. At the same time, during anticyclonic conditions there is trapping and accumulation of primary pollutants emitted in the boundary layer due to low atmospheric dispersion or stagnation. Also, the anticyclonic conditions are generally characterized by a pronounced mixing state and aging of boundary-layer air. The anticyclone over the central Mediterranean conducts air masses to the eastern Mediterranean region by the established northerly flow on the eastern fringe of the anticyclone. During the transport these air masses can be enriched with ozone precursors while passing over polluted areas of the European continent, especially over eastern Europe and the Balkans. Eventually, this can lead to an accumulation of ozone over the eastern Mediterranean region. In the Aegean the frequent presence of the central Mediterranean and the Balkan high pressure systems in combination with 


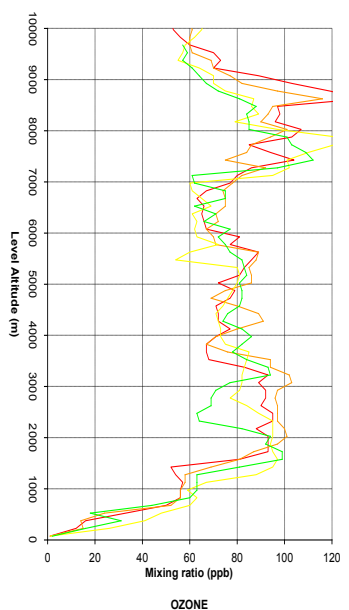

(a)

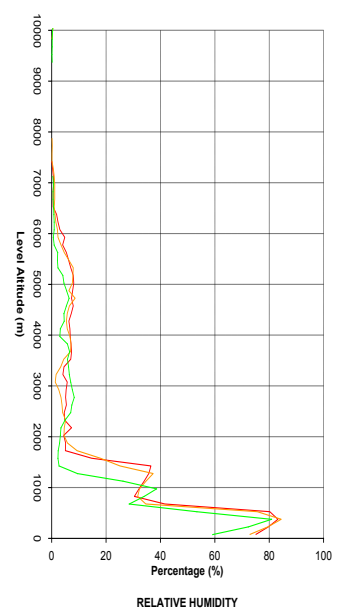

(b)

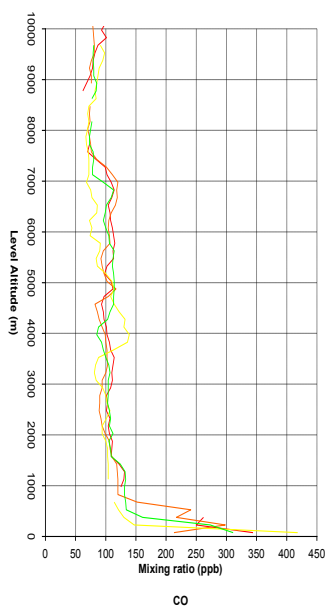

(c)

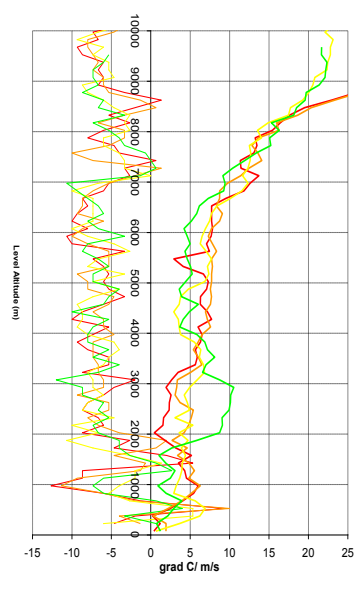

TEMPERATURE GRADIENT Per KM / WIND SPEED

(d)

Fig. 6. (a) Vertical profiles of summer (JJA) ozone over the eastern Mediterranean airport of Tel Aviv during the 3-day high ozone period in the lower troposphere, 30 July-1 August 2003 (Profiles: MD20030730084 (red), MA20030731024 (orange), MD20030731102 (yellow), MA20030801012 (green)); (b) same as (a) but for relative humidity; (c) same as (a) but for carbon monoxide (CO); (d) (left), same as (a) but for temperature gradient per km; (right), same as (a) but for wind speed.

the Middle Eastern low pressure system results in a persistent northerly flow in the boundary layer, frequently quite strong and containing high ozone amounts, which is in agreement with the results of field campaigns (Lelieveld et al., 2002; Zerefos et al., 2002), as well as long-term rural ozone measurements in the area (Kalabokas et al., 2000; Kouvarakis et al., 2002). In addition to the Aegean airports of Heraklion and Rhodes (Kalabokas et al., 2007), the Cairo airport might also be influenced by the characteristic summer northern current in the area, known as the Etesian winds (Repapis et al., 1977).

On the other hand, the lowest ozone values are associated with a low-pressure pattern covering central and eastern Europe, leading to westerly circulation over Mediterranean towards the eastern region, diffusing the air pollutants. They are also associated with the deepening and extension of the permanent summertime Middle Eastern low-pressure system. These low pressure conditions are associated with high dispersion and uplifting of boundary-layer air towards the lower troposphere, leading to low ozone and high relative humidity in the lower troposphere (boundary-layer air masses are poorer in ozone and richer in relative humidity compared to tropospheric air masses). It is also known that contrary to the high pressure systems linked to clockwise subsidence of tropospheric air, the low pressure systems are linked to upward counterclockwise movement of air masses, raising in fact the boundary-layer air into the free troposphere. The uplifting might not be only local and might concern larger areas, especially those located upwind of the studied airports. In this respect transport from the eastern Atlantic could be possible under prevailing western flow. It has to be added also that air uplifting might be reinforced by local topography, e.g. over the mountainous northwestern Africa under westerly flow. The upward air movement is enhanced by the fact that the weak pressure gradients during Mediterranean summers are linked to vertical instability due to thermal convection (Ziv et al., 2004).

From this analysis it turns out that a key factor leading to high lower troposphere ozone values in the eastern Mediterranean is the anticyclonic influence. Summer anticyclones are rich in ozone as they transport downwards the upper troposphere ozone, which has a marked midsummer peak over Europe (Thouret et al., 2006). Similar observations of high upper troposphere ozone levels during anticyclonic conditions have been reported in central Europe by analysing vertical MOZAIC profiles (Tressol et al., 2008) but also at rural sites in western, central and eastern Mediterranean following the analysis of surface ozone data (Kalabokas et al., 2008; Sánchez et al., 2008; Schürmann et al., 2009; Velchev et al., 2011). Especially for the eastern Mediterranean region, atmospheric conditions of strong summer anticyclonic subsidence in the lower troposphere, leading to high ozone concentrations, have been reported as a result of analysis of satellite data as well as large-scale atmospheric modelling simulations, which is in agreement with our observations ( $\mathrm{Li}$ et al., 2001; Eremenko et al., 2008; Foret et al., 2009; Liu et al., 2009; Coman et al., 2012; Richards et al., 2013).

In addition, following the examination of the composite weather maps for the tropospheric layers of $850 \mathrm{hPa}$ (Figs. 9, 11) as well as for the higher layers of $700 \mathrm{hPa}$ and $500 \mathrm{hpa}$ (not shown), during the day of observation but also during the days before the observation, it comes out that the characteristic synoptic weather patterns corresponding to highest and lowest ozone are quite uniform throughout the lower 

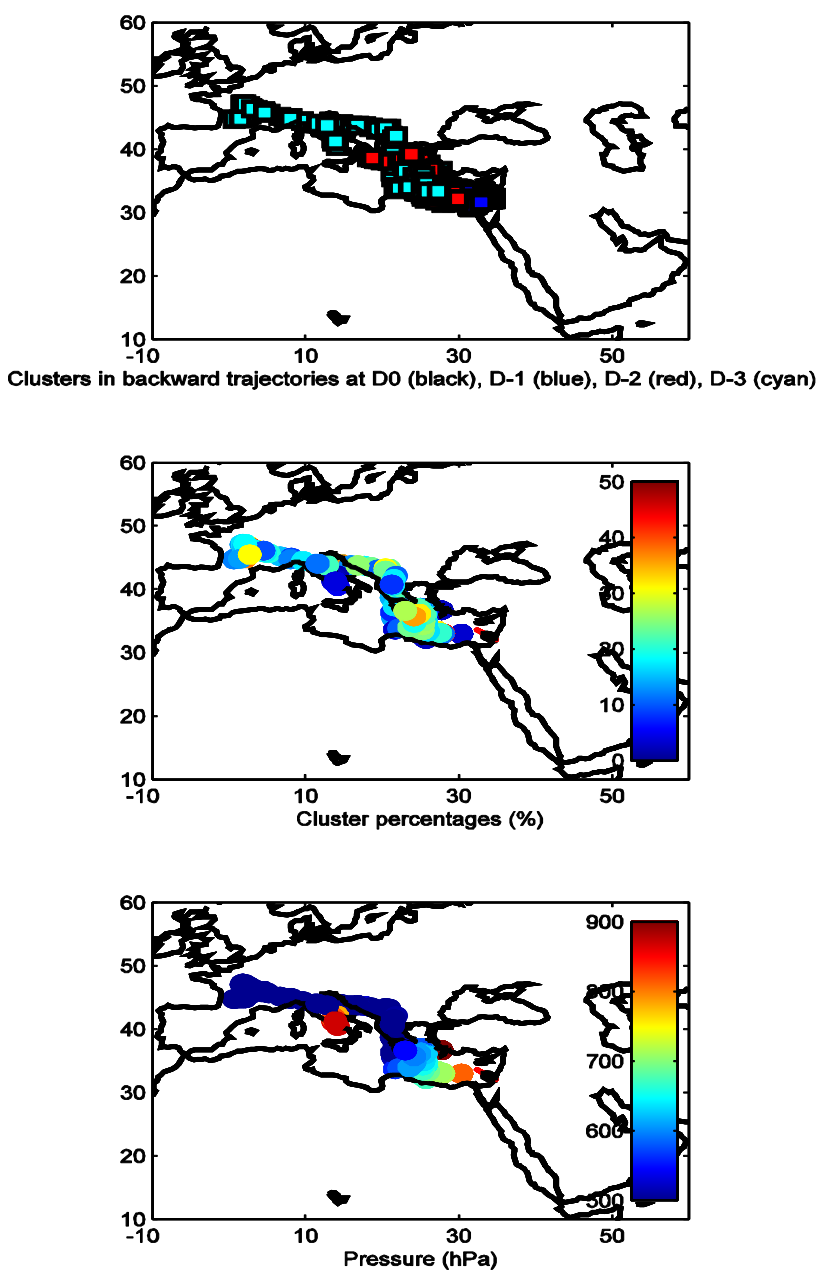

Fig. 7. Backward integration in time for 3 days for the MOZAIC vertical profile measurements and for air masses arriving at 1500$5000 \mathrm{~m}$ over Tel Aviv during a period with high ozone levels in the lower troposphere (31 July 2003, Flight: MD20030731102). The results are summarized on centroids of 5 clusters, and include latitude, longitude, pressure and percentage of representation every 12 hours. The results shown above are for the $1.5-5 \mathrm{~km}$ layer. Top plot shows the clusters positions at day 0 (black), day-1 (blue), day-2 (red), and day-3 (cyan). Middle plot shows the percentages of clusters at day-3. Finally, bottom plot shows the pressure of the clusters at day-3. The red line is the aircraft trajectory during ascent/descent.

troposphere, from the ground level to at least $5 \mathrm{~km}(500 \mathrm{hPa})$ and can be detected for several days before the selected measurements of highest or lowest ozone levels.

The calculation of convective available potential energy (CAPE) and convective inhibition (CIN), for the cases of the highest and lowest MOZAIC ozone vertical profiles over Cairo and Tel Aviv has been also carried out in order to define atmospheric instability and stability correspondingly. These calculations have been compared to the same-day calculations of the regular radio soundings performed over the airports of the eastern Mediterranean (provided by the upper air soundings unit of the University of Wisconsin, USA (http://weather.uwyo.edu/upperair/sounding.html). These results are in agreement with our argumentation. High CAPE values, indicating vertical instability, have been calculated during the lowest ozone days in the MOZAIC profiles as well as for the corresponding radio soundings over the airports of the eastern Mediterranean. On the contrary, high CIN values have been calculated during the highest ozone days.

According to the above observations, high levels of tropospheric ozone are accumulated on the top of the boundary layer during anticyclonic synoptic conditions in the eastern Mediterranean. Depending on the meteorological conditions, the time of the day and the particular geographical characteristics of each site in the area, tropospheric air may enter the boundary layer, causing fumigation as far as ozone is concerned, and leading to high surface ozone levels, which might exceed the air quality standards. Similar field observations on the influence of lower-troposphere ozone to the boundary layer and surface measurements have been reported recently at some locations of the Californian coast (Parrish et al., 2010).

Following the above analysis, some further remarks could be made on the shape and characteristics of the average profiles of the five examined eastern Mediterranean airports, as well as on their differences (Fig. 1). As already mentioned, the highest summer average ozone concentrations in the lower troposphere are observed over Cairo and Tel Aviv, while at the same time these airports show the lowest summer average relative humidity values in the lower troposphere (Fig. 1a). We could advance the hypothesis that the higher summer average levels of relative humidity in the lower troposphere over Rhodes, Heraklion and Antalya (35-50\%), located to the northern part of the eastern Mediterranean basin, in comparison to Cairo and Tel Aviv (10-30\%), indicates a more intense uplifting of boundary-layer air towards the lower troposphere over the former airports, which as mentioned before could be geographically extended and enhanced by the combination of the prevailing air flow with local topography. At the same time the lower tropospheric ozone values over Rhodes, Heraklion and Antalya are lower than the corresponding in Cairo and Tel Aviv while the CO values are higher over Rhodes, Heraklion and Antalya than in Cairo and Tel Aviv, which could be explained by a more intense uplifting of polluted boundary-layer air to the lower troposphere taking place over Rhodes, Heraklion and Antalya airports. In addition, over Rhodes, Heraklion and Antalya the decreasing temperature gradients are higher, indicating also vertical instability and stronger ascending movements that might be a result of a combination of sea-breeze and local topographical features (e.g. mountains close to shoreline), which is in agreement with the above hypothesis.

In general, the maximum vertical ozone concentrations over all the examined eastern Mediterranean airports are observed just above the boundary layer. Within the boundary layer, ozone is decreased on average in all airports, especially 


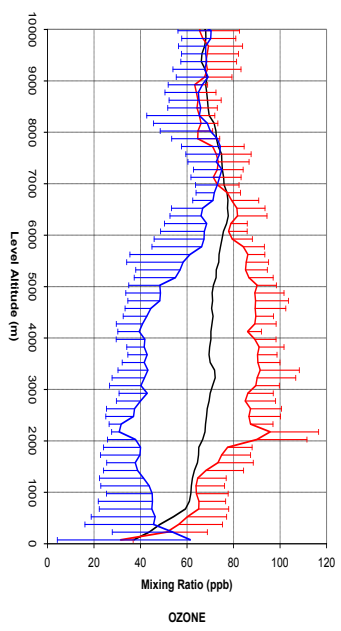

(a)

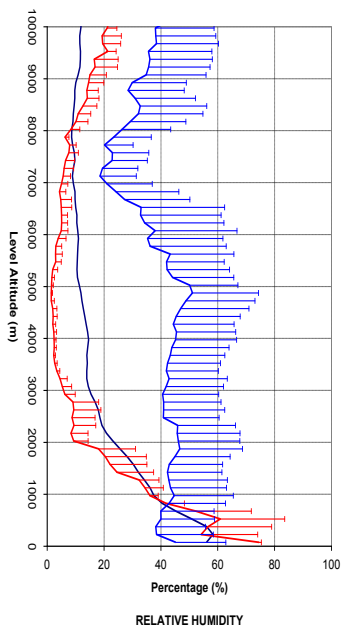

(b)

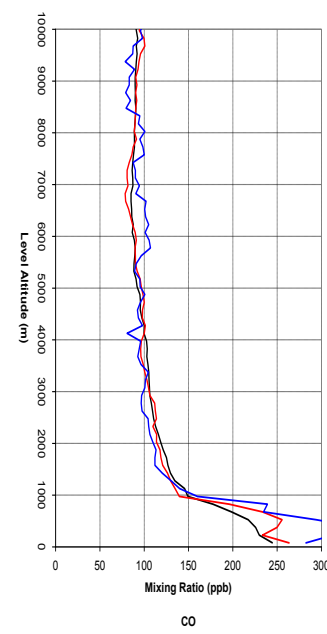

(c)

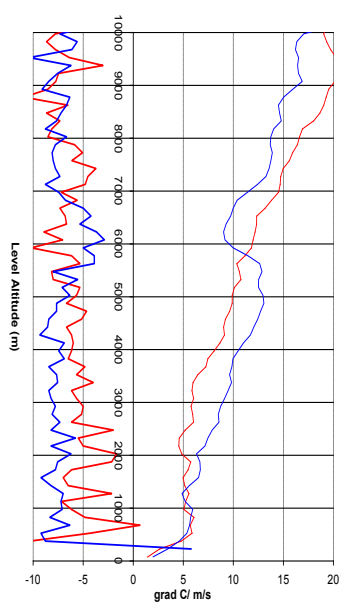

TEMPERATURE GRADIENT Per KM / WIND SPEED

(d)

Fig. 8. (a) Vertical profiles of summer (JJA) ozone over the eastern Mediterranean airport of Cairo for the $7 \%$ highest (red) and the $7 \%$ lowest (blue) ozone mixing ratios at 1500-5000 m; (b) same as (a) but for relative humidity; (c) same as (a) but for carbon monoxide (CO); (d) (left), same as (a) but for temperature gradient per km; (right), same as (a) but for wind speed. The black line in (a, b, c), shows the mean profile of the respective parameter.
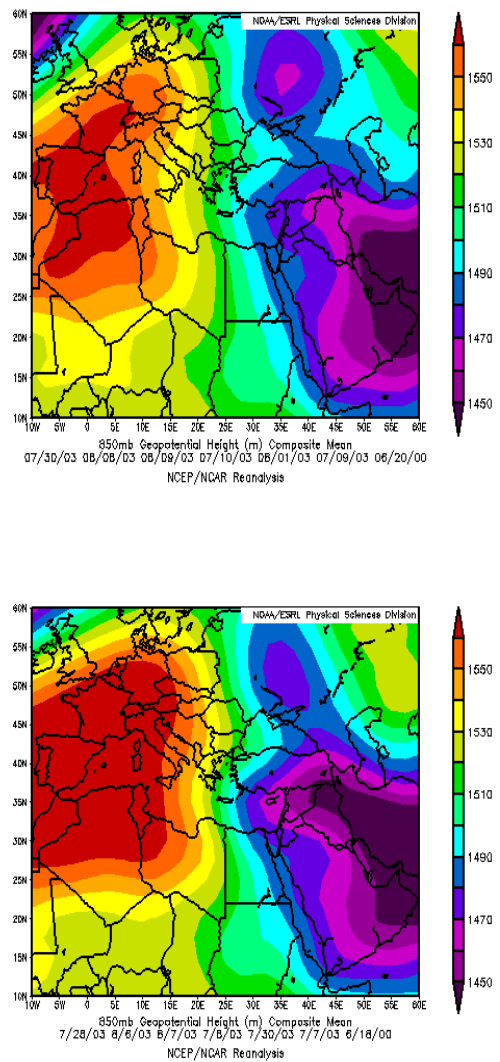
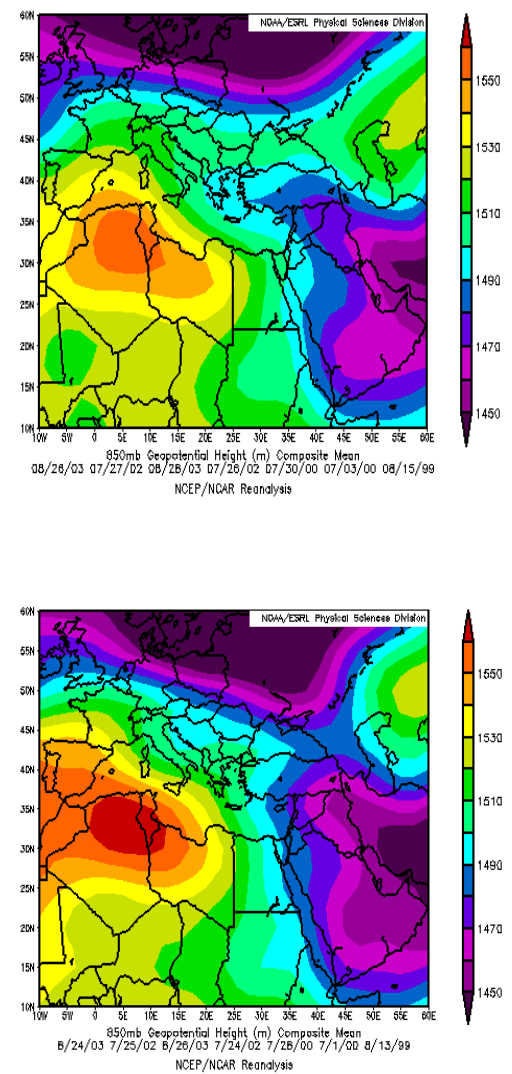

Fig. 9. Composite weather maps of geopotential heights at $850 \mathrm{hPa}$ of the $7 \%$ of the days with the highest ozone concentrations at the $1500-5000 \mathrm{~m}$ layer (left column) and of the $7 \%$ of the days with the lowest ozone concentrations at the 1500-5000 m layer (right column) in Cairo, during the day of the measurement (1st row) and 2-days ago (2nd row). 


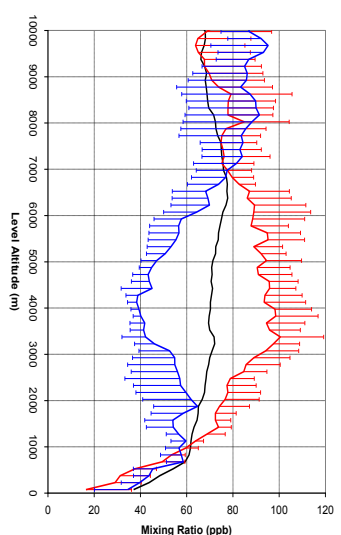

OZONE

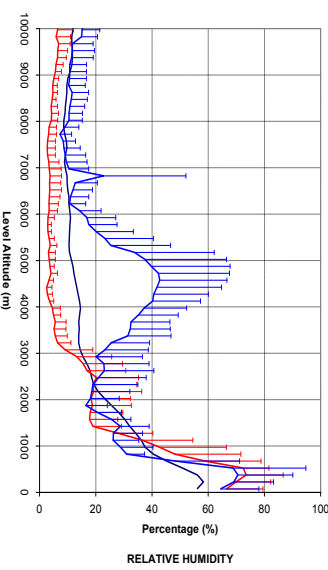

(b)

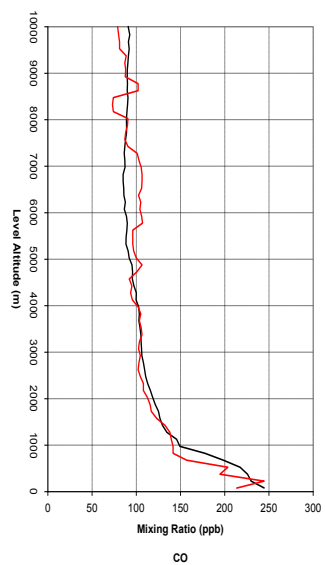

(c)

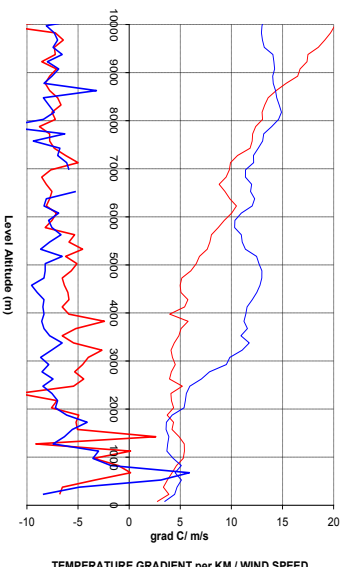

(d)

Fig. 10. (a) Vertical profiles of summer (JJA) ozone over the eastern Mediterranean airport of Tel Aviv for the $7 \%$ highest (red) and the $7 \%$ lowest (blue) ozone mixing ratios at 1500-5000 m; (b) same as (a) but for relative humidity; (c) same as (a) but for carbon monoxide (CO); (d) (left), same as (a) but for temperature gradient per km; (right), same as (a) but for wind speed. The black line in (a, b, c), shows the mean profile of the respective parameter. In (c) no CO data are available during lowest ozone days. There are missing profiles in (c).
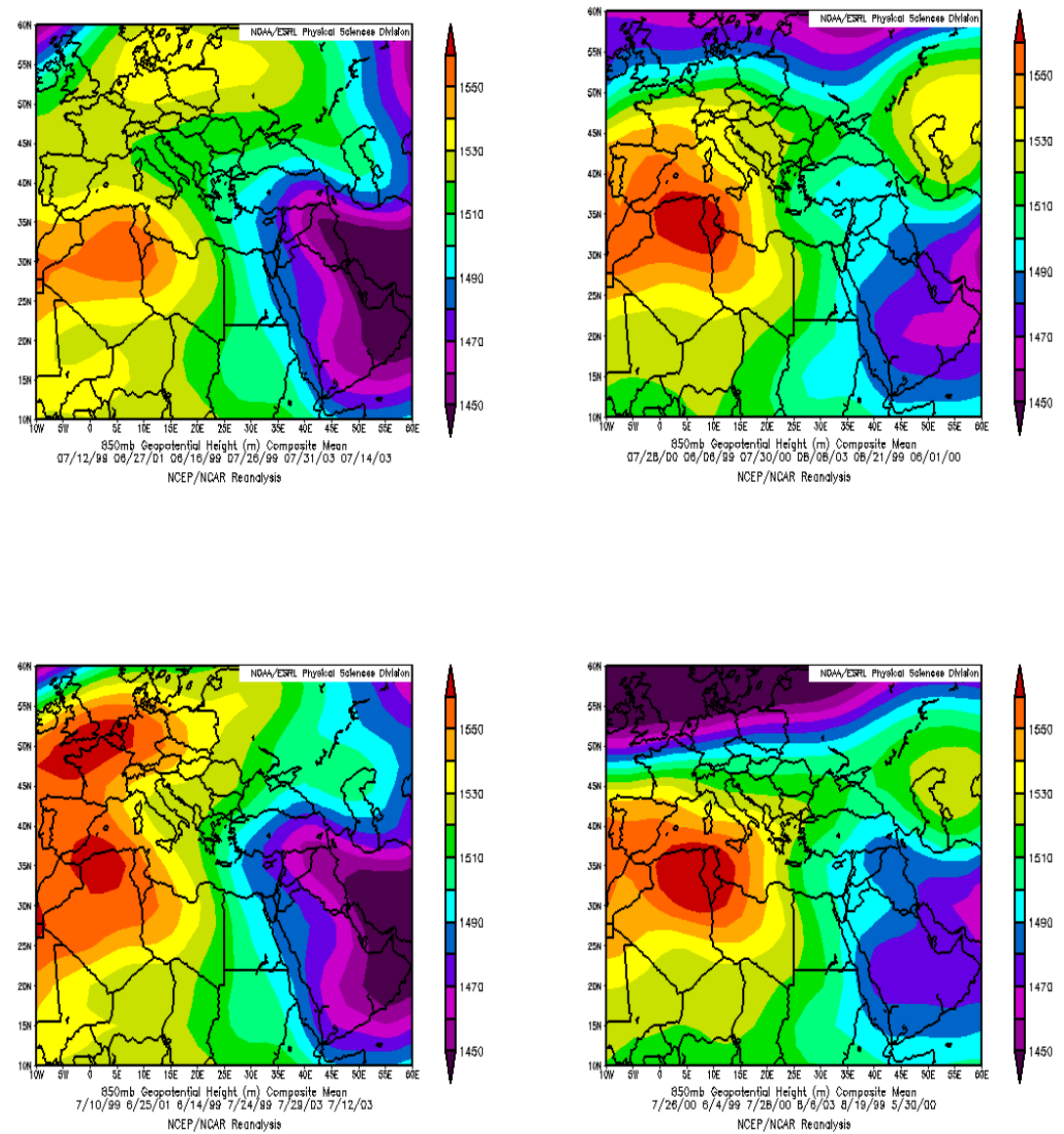

Fig. 11. Composite weather maps of geopotential heights at $850 \mathrm{hPa}$ of the $7 \%$ of the days with the highest ozone concentrations at the $1500-5000 \mathrm{~m}$ layer (left column) and of the $7 \%$ of the days with the lowest ozone concentrations at the 1500-5000 m layer (right column) in Tel Aviv, during the day of the measurement (1st row) and 2-days ago (2nd row). 
in Tel Aviv and Cairo, which might be attributed mainly to the influence of nitrogen oxides originating from local urban pollution, of atmospheric particles of mainly natural origin (e.g. desert dust), as well as local meteorological characteristics (e.g. sea-breeze cells). The analysis of the influences of the lower troposphere ozone levels to the boundary layer and surface ozone levels over the examined eastern Mediterranean airports will be the subject of a future investigation.

\section{Conclusions}

From the analysis of the summer vertical profiles of ozone measured in the period 1994-2008 in the framework of the MOZAIC project over five eastern Mediterranean airports, the following concluding remarks could be made:

a. The highest ozone levels in the lower troposphere (60$80 \mathrm{ppb}$ ) over all the examined eastern Mediterranean airports are associated with low relative humidity, temperature gradient and wind speed. They occur under high-pressure (anticyclonic) meteorological conditions and in particular the strengthening of the North African anticyclone and its extension towards central Europe and the Balkans, creating large-scale subsidence conditions resulting to high ozone levels to the lower troposphere and to the boundary layer through the process of summer thermal vertical mixing. The anticyclonic conditions in the area are also associated with a northern lower troposphere and boundary-layer flow transporting ozone and precursors from central and eastern Europe and/or the Balkans towards the eastern Mediterranean through the Aegean.

b. The lowest ozone levels are associated with high relative humidity, temperature gradient and wind speed corresponding to low pressure (cyclonic) meteorological conditions prevailing over eastern Europe and the Middle East creating uplifting of boundary-layer air towards the lower troposphere, enhanced by the significant thermal vertical instability in the region summer and occasionally by sea-breeze cells on the coastline.

c. The CO levels do not differ substantially between the two situations, which shows that high differences in tropospheric ozone mixing ratios (up to $50 \mathrm{ppb}$ ) might exist despite the comparable primary pollution levels in both examined air masses, indicating that local photochemistry could not be the main and only responsible factor for the observed high differences in ozone levels between the two examined conditions and atmospheric transport seems to play the major role.

Combining the above observations, it comes out that the lower-troposphere ozone variability over the eastern Mediterranean area is mainly controlled by the mesoscale synoptic meteorological conditions as well as by the local topographical and meteorological characteristics of each site.

Acknowledgements. This work was supported by the Research Committee of the Academy of Athens and the MariolopoulosKanaginis Foundation for the Environmental Sciences. The composite weather maps were provided by the NOAA/ESRL Physical Sciences Division, Boulder Colorado from their Web site at http://www.cdc.noaa.gov/. MOZAIC was funded by the European Commission. The authors acknowledge for the strong support of the European Commission, Airbus, and the Airlines (Lufthansa, Austrian, Air France) who carry the MOZAIC equipment free of charge and have performed the maintenance since 1994. MOZAIC is presently funded by INSU-CNRS (France), Meteo-France, and Forschungszentrum (FZJ, Julich, Germany). The MOZAIC data base is supported by ETHER (CNES and INSU-CNRS). C. Douvis and J. Kapsomenakis are also acknowledged for their help in the calculation of CAPE and CIN parameters of MOZAIC profiles.

Edited by: T. J. Dunkerton

\section{References}

Bates, D.: The effects of ozone on plants and people, in: Chemistry of the Atmosphere: Its Impact on Global Change, edited by: Calvert, J., Blackwell Scientific Publications, Oxford, 239-244, 1994.

Coman, A., Foret, G., Beekmann, M., Eremenko, M., Dufour, G., Gaubert, B., Ung, A., Schmechtig, C., Flaud, J.-M., and Bergametti, G.: Assimilation of IASI partial tropospheric columns with an Ensemble Kalman Filter over Europe, Atmos. Chem. Phys., 12, 2513-2532, doi:10.5194/acp-12-2513-2012, 2012.

Eremenko, M., Dufour, G., Foret, G., Keim, C., Orphal, J., Beekmann, M., Bergametti, G., and Flaud, J.-M.: Tropospheric ozone distributions over Europe during the heat wave in July 2007 observed from infrared nadir spectra recorded by IASI, Geophys. Res. Lett., 35, L18805, doi:10.1029/2008GL034803, 2008.

Finlayson-Pitts, B. and Pitts Jr., J.: Tropospheric air pollution: ozone, airborne toxics, polycyclic aromatic hydrocarbons, and particles, Science 276, 1045-1051, 1997.

Foret, G., Hamaoui, L., Schmechtig, C., Eremenko, M., Keim, C., Dufour, G., Boynard, A., Coman, A., Ung, A., and Beekmann, M.: Evaluating the potential of IASI ozone observations to constrain simulated surface ozone concentrations, Atmos. Chem. Phys., 9, 8479-8491, doi:10.5194/acp-9-8479-2009, 2009.

Gros, V., Williams, J., van Aardenne, J. A., Salisbury, G., Hofmann, R., Lawrence, M. G., von Kuhlmann, R., Lelieveld, J., Krol, M., Berresheim, H., Lobert, J. M., and Atlas, E.: Origin of anthropogenic hydrocarbons and halocarbons measured in the summertime european outflow (on Crete in 2001), Atmos. Chem. Phys., 3, 1223-1235, doi:10.5194/acp-3-1223-2003, 2003.

Kalabokas, P. D. and Repapis, C. C.: A climatological study of rural surface ozone in central Greece, Atmos. Chem. Phys., 4, 11391147, doi:10.5194/acp-4-1139-2004, 2004.

Kalabokas, P. D., Viras, L. G., Bartzis, J. G., and Repapis, C. C.: Mediterranean rural ozone characteristics around the urban area of Athens, Atmosph. Environ., 34, 5199-5208, 2000. 
Kalabokas, P. D., Volz-Thomas, A., Brioude, J., Thouret, V., Cammas, J.-P., and Repapis, C. C.: Vertical ozone measurements in the troposphere over the Eastern Mediterranean and comparison with Central Europe, Atmos. Chem. Phys., 7, 3783-3790, doi:10.5194/acp-7-3783-2007, 2007.

Kalabokas, P. D., Mihalopoulos, N., Ellul, R., Kleanthous, S., and Repapis, C. C.: An investigation of the meteorological and photochemical factors influencing the background rural and marine surface ozone levels in the Central and Eastern Mediterranean, Atmos. Environ., 42, 7894-7906, 2008.

Kalnay, E., Kanamitsu, M., Kistler, R., Collins, W., Deaven, D., Gandin, L., Iredell, M., Saha, S., White, G., Woolen, J., Zhu, Y., Chelliah, M., Ebisuzaki, W., Higgins, W., Janowiak, J., Mo, K. C., Ropelewski, C., Wang, J., Leetmaa, A., Reynolds, R., Jenne, R., and Joseph, D.: The NCEP/NCAR Reanalysis 40-year Project, B. Am. Meteorol. Soc., 77, 437-471, 1996.

Kourtidis, K., Zerefos, C., Rapsomanikis, S., Simeonov, V., Balis, D., Perros, P. E., Thomson, A. M., Witte, J., Calpini, B., Sharobiem, W. M., Papayiannis, A., Mihalopoulos, N., and Drakou, R.: Regional levels of ozone in the troposphere over eastern Mediterranean, J. Geophys. Res., 107, 8140, doi:10.1029/2000JD000140, 2002.

Kouvarakis G., Vrekoussis, M., Mihalopoulos, N., Kourtidis, K., Rappenglueck, B., Gerasopoulos E., and Zerefos, C.: Spatial and temporal variability of tropospheric ozone in the boundary layer above the Aegean Sea (eastern Mediterranean), J. Geophys. Res., 107, 8137, doi:10.1029/2000JD000081, 2002.

Li, Q., Jacob, D. J., Logan, J. A., Bey, I., Yantosca, R. M., Liu, H., Martin, R. V., Fiore, A. M., Field, B. D., Duncan, B. N., and Thouret, V.: A tropospheric ozone maximum over the Middle East, Geophys. Res. Lett., 28, 3235-3238, doi:10.1029/2001GL013134, 2001.

Lelieveld, J., Berresheim, H., Borrmann, S., Crutzen, P. J., Dentener, F. J., Fischer, H., de Gouw, J., Feichter, J., Flatau, P., Heland, J., Holzinger, R., Korrmann, R., Lawrence, M., Levin, Z., Markowicz, K., Mihalopoulos, N., Minikin, A., Ramanathan, V., de Reus, M., Roelofs, G.-J., Scheeren, H. A., Sciare, J., Schlager, H., Schultz, M., Siegmund, P., Steil, B., Stephanou, E., Stier, P., Traub, M., Williams, J., and Ziereis, H.: Global air Pollution crossroads over the Mediterranean, Science, 298, 794-799, 2002.

Liu, J. J., Jones, D. B. A., Worden, J. R., Noone, D., Parrington, M., and Kar, J.: Analysis of the summertime build-up of tropospheric ozone abundances over the Middle East and North Africa as observed by the Tropospheric Emission Spectrometer instrument, J. Geophys. Res., 114, D05304, doi:10.1029/2008JD010993, 2009.

Marenco, A., Thouret, V., Nédélec, P., Smit, H., Helten, M., Kley, D,. Karcher, F., Simon, P., Law, K., Pyle, J., Poschmann, G., Von Wrede, R., Hume, C., and Cook, T.: Measurements of ozone and water vapor by Airbus in-service aircraft: The MOZAIC airborne program. An overview, J. Geophys. Res., 103, 25631-25642, 1998.

Nedelec, P., Cammas, J.-P., Thouret, V., Athier, G., Cousin, J.-M., Legrand, C., Abonnel, C., Lecoeur, F., Cayez, G., and Marizy, C.: An improved infrared carbon monoxide analyser for routine measurements aboard commercial Airbus aircraft: technical validation and first scientific results of the MOZAIC III programme, Atmos. Chem. Phys., 3, 1551-1564, doi:10.5194/acp-3-15512003, 2003.
Nédélec, P., Thouret, V., Brioude, J., Sauvage, B., Cammas, J.P., and Stohl, A.: Extreme CO concentrations in the upper troposphere over northeast Asia in June 2003 from the in situ MOZAIC aircraft data, Geophys. Res. Lett., 32, L14807, doi:10.1029/2005GL023141, 2005.

Parrish, D. D., Aikin, K. C., Oltmans, S. J., Johnson, B. J., Ives, M., and Sweeny, C.: Impact of transported background ozone inflow on summertime air quality in a California ozone exceedance area, Atmos. Chem. Phys., 10, 10093-10109, doi:10.5194/acp10-10093-2010, 2010.

Repapis, C., Zerefos, C., and Tritakis, B.: On the Etesians over the Aegean, Proc. Acad. Athens, 52, 572-606, 1977.

Richards, N. A. D., Arnold, S. R., Chipperfield, M. P., Miles, G., Rap, A., Siddans, R., Monks, S. A., and Hollaway, M. J.: The Mediterranean summertime ozone maximum: global emission sensitivities and radiative impacts, Atmos. Chem. Phys., 13, 2331-2345, doi:10.5194/acp-13-2331-2013, 2013.

Rodwell, M. J. and Hoskins, B. J.: Monsoons and the dynamics of deserts, Q. J. R. Meteorol. Soc., 122, 1385-1404, 1996.

Rodwell, M. J. and Hoskins, B. J.: Subtropical anticyclones and summer monsoons, J. Climate, 14, 3192-3211, 2001.

Roelofs, G. J., Scheeren, H. A., Heland, J., Ziereis, H., and Lelieveld, J.: A model study of ozone in the eastern Mediterranean free troposphere during MINOS (August 2001), Atmos. Chem. Phys., 3, 1199-1210, doi:10.5194/acp-3-1199-2003, 2003.

Sánchez, M. L., García, M. A., Pérez, I. A., and de Torre, B.: Evaluation of surface ozone measurements during 2000-2005 at a rural area in the upper Spanish plateau, J. Atmos. Chem., 60, 137-152, 2008.

Scheeren, H. A., Lelieveld, J., Roelofs, G. J., Williams, J., Fischer, H., de Reus, M., de Gouw, J. A., Warneke, C., Holzinger, R., Schlager, H., Klüpfel, T., Bolder, M., van der Veen, C., and Lawrence, M.: The impact of monsoon outflow from India and Southeast Asia in the upper troposphere over the eastern Mediterranean, Atmos. Chem. Phys., 3, 1589-1608, doi:10.5194/acp-31589-2003, 2003.

Schürmann, G. J., Algieri, A., Hedgecock, I. M., Manna, G., Pirrone, N., and Sprovieri, F.: Modelling local and synoptic scale influences on ozone concentrations in a topographically complex region of Southern Italy, Atmos. Environ., 43, 4424-4434, 2009.

Seiler, W. and Fishman, J.: The distribution of carbon monoxide and ozone in the free troposphere, J. Geophys. Res., 86, 7255-7265, 1981.

Stohl, A., Hittenberger, M., and Wotawa, G.: Validation of the Langrangian particle dispersion model FLEXPART against largescale tracer experiments, Atmos. Environ., 24, 4245-4264, 1998.

Stohl, A., Forster, C., Frank, A., Seibert, P., and Wotawa, G.: Technical note: The Lagrangian particle dispersion model FLEXPART version 6.2, Atmos. Chem. Phys., 5, 2461-2474, doi:10.5194/acp-5-2461-2005, 2005.

Thouret, V., Marenco, A., Logan, J., Nédélec, P., and Grouhel, C.: Comparisons of ozone measurements from the MOZAIC airborne program and the ozone sounding network at eight locations, J. Geophys. Res., 103, 25695-25720, 1998.

Thouret, V., Cammas, J.-P., Sauvage, B., Athier, G., Zbinden, R., Nédélec, P., Simon, P., and Karcher, F.: Tropopause referenced ozone climatology and inter-annual variability (1994-2003) from 
the MOZAIC programme, Atmos. Chem. Phys., 6, 1033-1051, doi:10.5194/acp-6-1033-2006, 2006.

Traub, M., Fischer, H., de Reus, M., Kormann, R., Heland, H., Ziereis, H., Schlager, H., Holzinger, R., Williams, J., Warneke, C., de Gouw, J., and Lelieveld, J.: Chemical characteristics assigned to trajectory clusters during the MINOS campaign, Atmos. Chem. Phys., 3, 459-468, doi:10.5194/acp-3-459-2003, 2003.

Tressol, M., Ordonez, C., Zbinden, R., Brioude, J., Thouret, V., Mari, C., Nedelec, P., Cammas, J.-P., Smit, H., Patz, H.-W., and Volz-Thomas, A.: Air pollution during the 2003 European heat wave as seen by MOZAIC airliners, Atmos. Chem. Phys., 8, 2133-2150, doi:10.5194/acp-8-2133-2008, 2008.

Tyrlis, E., Lelieveld, J., and Steil, B.: The summer circulation over the eastern Mediterranean and the Middle East: influence of the South Asian monsoon. Clim. Dynam., 40, 1103-1123, doi:10.1007/s00382-012-1528-4, 2012.

Van Aalst, R., Fowler, D., Megie, G., Moussiopoulos, N., Warneck, P., Volz-Thomas, A., and Wayne R., in: "Photooxidants, Acidification and Tools; Policy Applications of EUROTRAC results" (Volume 10), edited by: Borrell, P., Hov, O., Grennfelt, P., and Builtjes, P., 41-69, Springer Verlag, Berlin, Heidelberg, New York, 1996.

Varotsos, C., Kalabokas, P., and Chronopoulos, G.: Atmospheric ozone concentration at Athens, Greece. Part II: Vertical ozone distribution in the troposphere, Atmos. Res., 30, 151-155, 1993.
Velchev, K., Cavalli, F., Hjorth, J., Marmer, E., Vignati, E., Dentener, F., and Raes, F.: Ozone over the Western Mediterranean Sea - results from two years of shipborne measurements, Atmos. Chem. Phys., 11, 675-688, doi:10.5194/acp-11-675-2011, 2011.

Volz-Thomas, A., Beekmann, M., Derwent, D., Law, K., Lindskog, A., Prevot, A., Roemer, M., Schultz, M., Schurath, U., Solberg S., and Stohl, A. : Tropospheric Ozone and its Control, in: Towards Cleaner Air for Europe - Science, Tools and Applications. Part 1: Results from the EUROTRAC-2; Synthesis and Integration (S\&I) Project, edited by: Builtjes, P. J.-H., Harrison, R. M., Midgley, P. M., and Tørsen, K., International Scientific Secretariat, Munchen, Germany, 73-122, 2003

Zbinden, R. M., Thouret, V., Ricaud, P., Carminati, F., Cammas, J.-P., and Nédélec, P.: Climatology of pure Tropospheric profiles and column contents of ozone and carbon monoxide using MOZAIC in the mid-northern latitudes $\left(24^{\circ} \mathrm{N}\right.$ to $\left.50^{\circ} \mathrm{N}\right)$ from 1994 to 2009, Atmos. Chem. Phys. Discuss., 13, 14695-14747, doi:10.5194/acpd-13-14695-2013, 2013.

Zerefos, C. S., Kourtidis, K. A., Melas, D., Balis, D., Zanis, P., Katsaros, L., Mantis, H. T., Repapis, C., Isaksen, I., Sundet, J., Herman, J,. Bhartia, P. K., and Calpini, B.: Photochemical Activity and Solar Ultraviolet Radiation (PAUR) Modulation factors: An overview of the project, J. Geophys. Res., 107, 8134, doi:10.1029/2000JD000134, 2002.

Ziv, B., Saaroni, H., and Alpert, P.: The factors governing the summer regime of the Eastern Mediterranean, Int. J. Climatol., 24, 1859-1871, 2004. 